\title{
Intervensi Latihan Keterampilan Sosial pada Pasien Perilaku Kekerasan
}

\author{
A.Nur Anna. AS, \\ Fakultas Kedokteran dan Ilmu Kesehatan Prodi DIII Keperawatan Universitas Muhammadiyah Makassar \\ E-mail: $\underline{\text { a.nur_anna@unismuh.ac.id }}$
}

\begin{abstract}
Abstrak
Pendahuluan: Perilaku agresif merupakan masalah terbesar yang sering terjadi dalam ruang rawat inap di pelayanan psikiatrik sehingga perlu menjadi prioritas utama, frekuensi agresi memberikan dampak yang negatif pada staf dan pasien lain perlu menjadi bahan pertimbangan. Metode: deskriptif yang dilakukan penelitian ialah jenis metode studi kasus dengan melakukan wawancara dan observasi. Hasil: latihan keterampilan sosial adalah latihan yang diberikan pada klien yang ingin memperbaiki keterampilan dalam melakukan hubungan sosial atau yang tidak mampu melakukan hubungan sosial dan penampilan yang sulit dipertahankan dalam berhubungan dengan orang lain dengan menggunakan prinsip-prinsip pembelajaran sosial. Latihan keterampilan sosial ini terdiri dari enam sesi, dimana setiap sesi waktu yang dibutuhkan 45 menit. Kesimpulan: Latihan keterampilan sosial dapat mengurangi resiko perilaku kekerasan. Rekomendasi: menerapkan latihan keterapila sosial sebagai intervensi pada pasien dengan perilaku kekerasan
\end{abstract}

Kata Kunci: Agresif, Latihan keterampilan Sosial, Perilaku kekerasan,

Abstrack

Background: Aggressive behavior is the biggest problem that often occurs in inpatient care at psychiatric services so it needs to be a top priority, the frequency of aggression has a negative impact on staff and other patients needs to be taken into consideration. Method: descriptive which conducts research on case study methods by conducting interviews and observations. Results: Social skills training given to clients who want to improve skills in social relations or who are unable to make social relations and creativity that are difficult in relation to others by using the principles of social learning. This social skills training consists of six sessions, where each session takes 45 minutes. Conclusions: Exercise skills can overcome problem solving problems. Recommendations: apply social skills training with intervention in patients aggressive behavior

Keywords: Aggressive, Social Skills Training, Violent Behavior,

\section{Pendahuluan}

Gangguan psikotik adalah gangguan psikis yang berat yang melibatkan hilang kontak dengan realita. Tanda-tanda medis sangat bervariasi baik pada fase akut maupun pada fase kronis (Oud et al, 2010). Psikosis merupakan gangguan tilikan pribadi yang menyebabkan ketidakmampuan seseorang menilai realita dengan fantasi dirinya. Hasilnya, terdapat realita baru versi orang psikosis tersebut. Psikosis adalah suatu kumpulan gejala atau sindrom yang berhubungan dengan gangguan psikiatri lainnya, tetapi gejala tersebut bukan merupakan gejala spesifik penyakit tersebut, seperti yang tercantum dalam kriteria diagnostik DSM-IV (Diagnostic and Statistical Manual of Mental Disorders) maupun ICD-10 (The International Statistical Classification of Diseases) atau menggunakan kriteria diagnostik PPDGJ- III (Pedoman Penggolongan dan Diagnosis Gangguan Jiwa). Arti psikosis sebenarnya masih bersifat sempit dan bisa yang berarti waham dan halusinasi, selain itu juga ditemukan gejala lain termasuk di antaranya pembicaraan dan tingkah laku yang kacau, dan gangguan daya nilai realitas yang berat. Oleh karena itu psikosis dapat pula diartikan sebagai suatu kumpulan gejala/terdapatnya 
gangguan fungsi mental, respon perasaan, daya nilai realitas, komunikasi dan hubungan antara individu dengan lingkungannya (Maslim, 2013).

Sedangkan dalam Takeuchi dan Lemington (2013) menyebutkan bahwa tanda gejala yang muncul pada gejala psikotik adalah Halusinasi, delusi, disorganisasi, perilaku aneh, Peningkatan kecemasan, permusuhan, dan psikomotor, Kemudian juga dicatat dalam kategori berikut, masing-masing: agitasi, agresi, dan aktivasi. Pada jurnal ini menyebutkan tanda dan gejala lebih lengkap yang miliki oleh psikotik, tanpa disertai dengan gejala fisik.

Menurut Van, Hannsen, Bijl, \& Vollebergh (2001) dalam penelitiannya dari 7.076 prevalensi pada pasien-pasien psikotik, didapatkan bahwa 95\% memiliki gejala delusi dan atau halusinasi. Pasien psikotik yang nalar (ego)-nya sudah runtuh, maka halusinasi tersebut dianggap real dan tak jarang ia bereaksi terhadap halusinasi dengar, hal ini membuat pasien terkadang dikategorikan dalam pasien-pasien skizophrenia jika terjadi pemburukan lebih lanjut. Hal ini di dukung oleh penelitian Zammit, Allebeck, Andreasson, Lundberg, \& Lewig, (2002) memperkirakan bahwa di Canada terdapat $13 \%$ kasus-kasus skizophrenia yang berhubungan dengan perburukan pasien-pasien gangguan psikotik.

Perilaku agresif merupakan masalah terbesar yang sering terjadi dalam ruang rawat inap di pelayanan psikiatrik sehingga perlu menjadi prioritas utama, frekuensi agresi memberikan dampak yang negatif pada staf dan pasien lain perlu menjadi bahan pertimbangan (Tremmery et al 2014).

Dalam rawat inap pasien gangguan mental memberikan pelayanan yang aman dan lingkungan yang terapeutik untuk pasien. Dalam pencapaian tujuan ini sering kali ada faktor yang mempengaruhinya sehingga tidak tercapai seperti perilaku. Perilaku kekerasan adalah tindakan pasien yang dapat mencederai diri sendiri atau orang lain beresiko mengalami cedera, ini termasuk agresif verbal dan fisik yang lazim terjadi di ruang rawat inap (Papadopoulos et al, 2012).

\section{Metode}

Menggunakan jenis metode deskriptif yang dilakukan penelitian ialah jenis metode studi kasus. Salah satu jenis penelitian deskriptif adalah berupa penelitian dengan metode atau pendekatan studi kasus.Studi kasus termaksut dalam penelitian analisis deskriptif, yaitu peneliti yang dilakukan terfokus pada suatu kasus tertentu untuk diamati dan dianalisis secara cermat sampai tuntas (Siswanto, Susila \& Suyanto, 2015). Pasien diobservasi dengan batasan terperinci, memiliki pengambilan data yang mendalam dan menyertakan berbagai sumber informasi.

\section{Hasil}

Penulis melakukan pengkajian pada tanggal 4 desember 2015 dengan hasil pengkajian: Tn"A" usia 23 tahun, alamat Cisarantem, Arcamnik Bandung, status belum menikah, pendidikan terakhir S1 Informatika. Keluhan utama klien yaitu mendengarkan suara-suara pada telinga kanan dan kiri.

Faktor predisposisi: tidak ada keluarga yang mengalami gangguan jiwa. Klien mengalami dislokasi pada sendi bahu terjadi 4 kali, mulai dari SMA karena main bulu tangkis, saat bermain dengan adiknya, saat kuliah dengan main tarik tambang dan kesenggol dengan orang lain. Klien mengatakan ingin bertemu dengan bapak dan meminta maaf karena banyak salah, klien mengatakan pernah melakukan kesalahan dimasa lalu (klien tidak mau menyebutkan kesalahan apa yang dilakukan). Klien mengatakan ingin kaya jadi ketemu dengan pak Bill minta didoakan untuk menjadi orang kaya. 
Faktor presipitasi: Klien pertama kali dirawat di Rumah sakit jiwa. Menurut informasi dari klien bahwa di rumah klien marah-marah dan menyuruh bapak untuk bertobat karena banyak dosa. Berdasarkan informasi dari petugas ruangan Klien baru selesai kuliah 3 bulan yang lalu dan belum bekerja. Sejak dua minggu yang lalu (sekitar tanggal 16 November 2015) klien mengalami perubahan perilaku: sering melamun, banyak menulis tentang surga dan neraka, lebih pendiam, jarang bergaul. Pada tanggal 27 November 2015 berbicara sendiri dalam kamar, marahmarah pada keluarga.

Penilaian terhadap stressor: Klien sulit berkosentrasi karena selalu menoleh ke kiri dan kanan karena ada suara-suara, flight of idea, terjadi bloking pada saat interaksi dengan klien. Klien marah-marah dan curiga, gelisah, agitasi. Sumber koping: klien merasa terganggu dengan suara-suara yang didengarnya karena disuruh menjauhi pak asep karena jahat (suara pada telinga kiri) padahal sebenarnya pak asep sangat baik sama dengan bapak baiknya, keluarga sangan mendukung untuk kesembuhan klien, klien berobat dengan menggunakan BPJS mandiri, klien sangat ingin sembuh dan bisa pulang ke rumah meminta maaf pada bapak dan ibu.

Penilaian status kesehatan mental 1) Penampilan: penampilan klien sesuai dan klien cukup bersih, rambut klien pendek, gigi bersih, badan bersih dan tidak berbau, 2) pembicaraan: Selama pengkajian klien berbicara lambat dan kadang pasien blocking tetapi tetap kooperatif. Klien mau mengobrol dan menerima masukan, 3) aktivitas motorik: gelisah, agitasi, pandangan mata tajam, mondar mandir, mulut klien komat-kamit pada saat klien sendiri, sering menoleh ke kanan dan kiri, 4) Alam perasaan: sedih pengen ketemu dengan bapak, takut karena ada suara yang menyuruh bunuh diri pada telinga kiri, dan klien mengatakan khwatir dengan ibunya (klien tidak mau mengatakan alasan khwatir dengan ibunya), 5) Afek: labil, 6) interaksi selama wawancara: kontak mata kurang dan klien terkadang menoleh ke kanan dan kiri, sering mengusap muka, berhati-hati ketika menyampaikan sesuatu, 7) Persepsi: klien mendengarkan suara-suara pada telinga kanan dan kiri. Isi suara pada telinga kanan adalah anak baik, harus bertobat sedangkan pada telinga kiri adalah harus menjauhi pak asep (keluarga dari bapak) karena pak asep itu jahat sedangkan pada kenyataannya pak asep sebenarnya baik banget sama dengan bapak dan menyuruh bunuh diri (pada tanggal 5 Desember 2015),

8) Isi pikir: ide yang terkait bunuh diri karena mendengarkan suara untuk bunuh diri, obsesi klien harus bertobat dan meminta maaf pada bapak karena aang berdosa, aang pernah ke pak bill untuk minta didoakan agar kaya dan bisa berbagi terhadap sesame, 9) Proses pikir: saat pengkajian klien sering terjadi blocking, pembicaraan sirkumtansial dan flight of ideas, 10) Tingkat kesadaran: pada saat pengkajian klien nampak bingung dan tidak mengalami disorientasi waktu, tempat, dan orang, 11) Memori: klien tidak mengalami gangguan daya ingat, 12) Tingkat konsentrasi dan berhitung: klien tidak dapat konsentrasi karena klien nampak menoleh kekiri dan kekanan saat dilakukan pengkajian, 13) Kemampuan penilaian: tidak mengalami gangguan dan 14) daya tilik diri: klien tidak mengalami gangguan daya tilik diri dan menerima bahwa dirinya sedang sakit. Pada saat pengkajian klien mengatakan mendengarkan suara-suara dan saya mengatakan bahwa saya mengetahui bahwa klien sedang mendegarkan suara-suara tetapi hanya Tn"A" yang mendengarkannya dan saya tidak mendengarkan. Tanda-tanda vital: TD 120/70, N: 88x/menit, P: 24x/menit. Obat klien mendapatkan antipsikotik yaitu clozapine $50 \mathrm{mg}$, aturan minum 1-0-1.

Intervensi keperawatan yang digunakan pada Tn"A" untuk mengatasi permasalahan yang didapatkan adalah intervensi konvensional dan terapi spesialis. Di berikan intervensi latihan keterampilan sosial. Menurut Bembry, Zentgraf, \& Baffour (2013) latihan keterampilan sosial adalah latihan yang 
diberikan pada klien yang ingin memperbaiki keterampilan dalam melakukan hubungan sosial atau yang tidak mampu melakukan hubungan sosial dan penampilan yang sulit dipertahankan dalam berhubungan dengan orang lain dengan menggunakan prinsipprinsip pembelajaran sosial. Latihan keterampilan sosial ini terdiri dari enam sesi, dimana setiap sesi waktu yang dibutuhkan 45 menit.

Berikut ini sesi-sesi pelaksanaan latihan keterampilan sosial:

Sesi 1: orientasi, pengkajian dan harga diri: Komunikasi verbal meliputi mengucapkan salam, memperkenalkan diri, bertanya dan menjawab mengenai harga diri. Kemudian berdiskusi dengan pasien bagaimana membangun harga diri. Komunikasi nonverbal meliputi kontak mata, tersenyum, berjabat tangan, duduk tegak/posisi tubuh saat berkomunikasi.

Sesi 2: Hak dan Tanggung jawab untuk diri sendiri, orang lain dan masyarakat: pada sesi ini melatih kemampuan untuk bertanya tentang hak-hak apa yang dimiliki seseorang? Mereka diminta untuk mendiskusikan hak mereka sebagai pasien dan pembahasana tanggung jawab pasien adalah kepatuhan untuk minum obat yang diresepkan, kepatuhan mereka untuk gaya hidup sehat dan mencegah untuk masuk ke rumah sakit lagi, menjaga lingkungan tetap bersih.

Sesi 3: perasaan dan emosi: pasien yang didiagnosa skizoprenia sering kali sulit untuk memahami emosi dan perasaan. Yang dilakukan adalah modifikasi perilaku.

Sesi 4: Marah: sesi ini dirancang untuk mengidentifikasi fisik, emosional dan lingkungan yang dapat memicu kemarahan ketika berkomunikasi dengan orang lain, mengakui kemarahan pada orang lain, dan bagaimana kemarahan bisa membantu (misalkan orang-orang yang melanggar aturan atau norma-norma).
Sesi 5: Resolusi konflik: pada sesi ini pasien diperkenalkan dengan keterampilan negosisasi sebagai cara terbaik untuk menghindari interaksi negatif dengan yang lain. Empat langkah yang dilakukan 1) berpikir tentang masalah dengan sesedikit mungkin emosi, 2) tunduk mendengarkan pandangan orang lain, 3) menentukan masalah bersama-sama dan 4) mengungkapkan pendapat untuk pemecahan masalah. Sesi 6: Menajemen marah: sesi ini menekankan cara-cara alternatif untuk mengatasi kemarahan. Pasien diberi kesempatan untuk menuliskan cara menghindari marah dengan menyalurkan energi kedalam tindakan fisik positif.

\section{Pembahasan}

Perpaduan antara terapi perilaku kognitif dan latihan keterampilan sosial digunakan sebagai intervensi karena dapat meningkatkan fungsi sosial individu yang menderita skizoprenia (Woolf, 2010). Sedangkan menurut Kurts and Mueser (2008) bahwa hasil penelitiannya menunjukkan bahwa latihan terapi sosial dapat meningkatkan fungsi sosial pada pasien skizoprenia. Intervensi cognitivebehavioral social skill training dapat memberikan efek positif untuk mengurangi keputusasaan pada pasien dan berfungsi dalam pengobatan pasien (Emmerson, Grandholm, Link, McQuaid, \& Jeste, 2009). Terjadinya peningkatan gejala negatif setelah diberikan intervensi pelatihan keterampilan sosial selama enam bulan (Amell and Llandrich, 2008).

Penelitian yang dilakukan intervesi pada pasien dengan perilaku kekerasan berdasarkan hasil penelitian Bernstein, \& Saladino (2007) menyebutkan bahwa dalam merawat pasien gangguan mental dengan perilaku kekerasan didalam perawatan yaitu dengan menggunakan prinsip memberikan perawatan yang efektif dan aman, membangun hubungan dengan pasien selama 
proses penerimaan, memanfaatkan strategi pencegahan krisis, obat yang sesuai, lingkungan yang aman, konseling dan intervensi pengajaran kesehatan serta menggunakan teknik resolusi konflik. Sedangkan dalam penelitian yang dilakukan oleh Anderson, \& West (2011) menyebutkan bahwa intervensi yang dapat dilakukan yaitu dengan melakukan pendekatan pada pasien agar dapat mengkomunikasikan secara lisan mengkomunikasikan perasaan secara lisan, memenuhi kebutuhan melalui asertif bukan perilaku agresif, mengenali tingkat kemarahan mereka sendiri dan menghindari diri dari situasi. Selain itu pasien juga dapat belajar bagimana pikiran yang negatif dapat berpengaruh pada perilaku agresif.

Berdasarkan hasil penelitian diatas bahwa pasien yang mengalami perilaku kekerasan/mengancam jiwa memang perlu dilakukan restraint/seklusi, tetapi perlu diingat bahwa itu merupakan pilihan terakhir dalam intervensi dan jika keamanan orang atau orang lain terancam, langkah ini tidak boleh digunakan sebagai pengobatan untuk seseorang, tetapi sebagai kepentingan perlindungan (Mereneau-Cote., \& Morin, 2013). Hal ini di dukung oleh penelitian yang dilakukan oleh Bridgett, Valentino, \& Hayden (2012) dengan melakukan pengukuran depresi pada anak didapatkan bahwa mempunyai karateristik temperamental mempunyai pengaruh dalam pemberian intervensi restraint atau seklusi yang dirawat di rumah sakit.

Sebuah artikel yang ditulis oleh Carr (2012) menyebutkan bahwa restraint dapat dilakukan pada pasien dengan gangguan mental sebagai pilihan terakhir dalam menghadapi dan pengobatan diri pasien dengan keadaan yang mengancam jiwa. Sama halnya dengan penelitian yang dilakukan oleh Gerace, Mosel, Oster, \& Muir-Cochrane (2013) yang menyebutkan bahwa tindakan restrain dapat dilakukan pada awal perawatan dengan tujuan untuk mencegah agresi yang berlebihan dengan resiko yang besar yang mengancam jiwa.

\section{Kesimpulan}

Individu yang mengalami gangguan jiwa terjadi kesulitan dalam mempersepsikan realita dengan fantasi dirinya sehingga terjadi kesulitan dalam memenuhi kebutuhannya sendiri, kesulitan dalam interaksi dengan keluarga maupun masyarakat. Perilaku kekerasan adalah tindakan pasien yang dapat mencederai diri sendiri atau orang lain beresiko mengalami cedera, ini termasuk agresif verbal dan fisik yang lazim terjadi. Latihan keterampilan sosial dapat mengurangi resiko perilaku kekerasan. Ucapan Terima Kasih

\section{Daftar Pustaka}

Amell, R. C., \& Llandrich, J. O. (2008). Validity of a social skills training program for schizopherenic patients. Actas Eps Psiquiart, 36(3), 123-132. Retrieved from http://web.a.ebscohost.com/ehost/pdf viewer/pdfviewer?sid=08941531 c0de-4d3e-a992-

88167d66e231\%40sessionmgr4005\& vid=0\&hid $=4109$

Anderson, A., \& West, S. G. (2011). Violence Against Mental Health Professionals: When the Treater Becomes the Victim. Innovations In Clinical Neuroscience, 8(3), 3439.Anderson, A., \& West, S. G. (2011). Violence Against Mental Health Professionals: When the Treater Becomes the Victim. Innovations In Clinical Neuroscience, 8(3), 34-39.

Bembry, J. X., Zentgraf, S., \& Baffour, T. (2013). Social skills training through poetry therapy: a group intervention with schizophrenic patient. Journal of Poetry Therapy, 26 (2), 73-82. Retrieved from 
http://dx.doi.org/10.1080/08893675.2

013.794534

Bridgett, D., J., Valentino, K., \& Hayden, L., C. (2012). The contribution of children's temperamental fear and effortful control to restraint and seclusion during inpatient treatment in a psychiatric hospital. Child psychiatric, 821-836. doi:10.1007/s10578-012-0298-x

Carr, P. G. (2012). The use of mechanical restraint in mental health: a catalyst for change?. Journal Of Psychiatric \& Mental Health Nursing, 19(7), 657$664 \quad 8$ p. doi:10.1111/j.13652850.2012.01912.x

Emmerson, L. C., Grandholm, E., Link, P. C., McQuaid, J. R \& Jeste, D. V. (2009). Insight and treatment outcome with cognitive-behavioral social training for older people with schizophrenia. Journal of Rehabilitation Research \& Develovement, 46(8), 1053-1058. Doi:1682/JRRD.2009.04.0042

Gerace, A., Mosel, K., Oster, C., \& MuirCochrane, E. (2013). Restraint use in acute and extended mental health services for older persons. International Journal of Mental Health Nursing, 22(6), 545-557 13p. doi:10.1111/j.14470349.2012.00872.x

Kurtz, M. M., \& Mueser. K. T. (2008). A meta-analysis of controlled research on social skills training for schizophrenia. Journal of Consulting and Clinical Psychology, 76(3), 491504. Doi:10.1037/0022006X.76.3.491

Maslim, R. (2013). Diagnosis gangguan jiwa rujukan dari PPDGJ-III dan DSM-5. Jakarta: PT Nuh Jaya

Merineau-Cote, J., \& Morin, D. (2013). Correlates of restraint and seclusion for adults with intellectual disabilities in community service. Journal of Intellectual Disabilities Research, 57,
$2 . \quad 82-90$. doi: $10.1111 / \mathrm{j} .1365-$ 2788.2012.01601.x

Oud, M. J., Schuling, J., Greoenier, K. H., Verhaak, P. F., Slooff, C. J., Dekker, J. H., \& Jong, B. M. (2010). Care provide by general practionerts to patients with psychotic disorders: a cohort study. BMC Family Practice, 11(92), 1-6. http://www.biomedcentral.com/14712296/11/92

Papadopoulos, C., Ross, J., Stewart, D., Dack, C., James, K., \& Bowers. (2012). The antecedents of violence and aggression within psychiatric inpatient settings. Acta Psychiatr Scand 2012: 125: 425-439. DOI: 10.1111/j.1600-0447.2012.01827.x

Takeuchi, H \& Remington, G. (2013). A systematic review of reported cases involving psychotic symptoms worsened by aripiprazole in schizophrenia or schizoaffective disorder. Psycho pharmakologi. 228:175-185 DOI 10.1007/s00213013-3154-1

Tremmery, S., Danckaerts, M., Bruckers, L., Molenbersghs, G., Hert, M. D., Wampers, M., De Vare, J., \& De Decker, A. (2014). Registration of aggressive incidents in an adolescent forensic psychiatric unit and implications for further practice. Eur Child Adolesc Psychiatry (2014) 23:823-833. DOI 10.1007/s00787014-0534-y

Van Os, J., Hanssen, M., Bijl, R. V., \& Vollebergh, W. (2001). Prevalence of psychotic disorder and community level of psychotic symptomsan urban-rural comparison. Article of Arch Gen Psychiatry. $58 \quad$ (7), 663-668. doi:10.1001/archpsyc.58.7.663

Woolf, E. (2010). The effect of social skills training on individuals with schizopherenia. Pacific University Common Knowledge. Retrieved from http://commons.pacificu.edu/cgi/viewco ntent. cgi?article $=1016 \&$ context $=$ otmh 
Zammit, S., Allebeck, P., Andreasson, S., Lundberg, I., \& Lewig, G. (2002). Self reported cannabis use as a risk factor for schizophrenia in Swedish conscripts of 1969: Historical cohort study. British Medical Journal 325, 1199-1203 